Jurnal Pemberdayaan: Publikasi Hasil Pengabdian kepada Masyarakat

Vol. 2, No. 1, April 2018, Hal. 177-186

ISSN: 2088 4559; e-ISSN: XXXX-XXXX

DOI:

\title{
PEMBERDAYAAN MASYARAKAT DESA TEMUWUH, KECAMATAN DLINGO MELALUI KEGIATAN PELATIHAN PENGOLAHAN SUMBER BAHAN PANGAN LOKAL
}

\author{
Septian Emma Dwi Jatmika, Welny Putri Maharani, Fivetha Titik Oktavia, Ofhie Putri \\ Universitas Ahmad Dahlan, Yogyakarta \\ Email: septiaemma@ikm.uad.ac.id
}

\begin{abstract}
ABSTRAK
Potensi yang dimiliki Desa Temuwuh dalam menghasilkan bahan pangan sangat baik, sehingga inovasi terhadap bahan pangan yang tersedia diperlukan. Umumnya, masyarakat mengolah bahan pangan seperti singkong, jahe dan tempe dengan cara yang sederhana. Oleh karena itu, mahasiswa KKN UAD tergerak untuk memberdayakan masyarakat dengan memberikan pelatihan membuat kue yang terbuat dari tepung mokaf, serbuk jahe dan nugget tempe. Tujuan pelatihan ini adalah untuk memberikan bekal pengetahuan dan keterampilan usaha bagi masyarakat Desa Temuwuh. Metode pelaksanaan pelatihan meliputi kegiatan penyuluhan kandungan gizi dan praktek pembuatan produk dan pelatian praktik pengolahan sumber bahan pangan lokal. Dampak dari adanya kegiatan ini adalah bertambahnya pengetahuan dan keterampilan masyarakat tentang cara mengolah bahan pangan dan berkembangnya suatu prospek usaha.
\end{abstract}

Kata kunci : pemberdayaan, pelatihan, bahan pangan local

\begin{abstract}
The potential of Temuwuh Village in producing food is very good, so innovation on available food is needed. Generally, people process food such as cassava, ginger and tempeh in a simple way. Therefore, UK KKN students are moved to empower the community by providing training on making cakes made from mokaf flour, ginger powder and tempe nugget. The purpose of this training is to provide knowledge and business skills for the people of Temuwuh Village. The method of implementing the training includes the activities of nutrition counseling and product manufacturing practices. The impact of this activity is the increase of public knowledge about how to process the food and the development of a business prospect.
\end{abstract}

Keywords : empowerment, training, local foodstuffs 


\section{PENDAHULUAN}

Masyarakat memerlukan makanan untuk bertahan hidup tentunya. Bahan pangan saat ini susah untuk didapatkan dan mahal harganya. Pengolahan bahan pangan yang telah ada merupakan altenatif bagi masyarakat untuk mendapatkan bahan pangan yang dibutuhkan. Selain itu, potensi yang dimiliki oleh Desa Temuwuh cukup mumpuni untuk dilakukannya permberdayaan masyarakat dalam pengolahan bahan pangan tradisional. Pemberdayaan masyarakat dalam program KKN ini dilaksanakan di 3 dusun yang berada di Desa Temuwuh, yaitu Dusung Kapingan, Jambewangi dan Ngelampengan. Sumber pangan yang diolah menjadi lebih kreativ di masing-masing dusun berbeda-beda. Dusun Kapingan mengolah singkong menjadi tepung mokaf untuk selanjutnya dapat dikreasikan menjadi produk kue, Dusun Jambewangi mengolah jahe menjadi serbuk jahe dan Dusun Ngelampengan mengolah tempe menjadi nugget tempe.

Mocaf adalah produk tepung dari ubi kayu (manihod esculenta crantz) yang diproses menggunakan prinsip memodifikasi sel ubi kayu secara fermentasi. microba yang tumbuh menyebabkan perubahan karakteristik dari tepung yang dihasilkan berupa naiknya viskositas, kemampuan gelasi, daya rehidrasi, dan kemudahan melarut. Mikroba juga menghasilkan asam-asam organik, terutama asam laktat yang akan terimhibisi dalam bahan, dan ketika bahan tersebut diolah akan dapat menghasilkan aroma dan citra rasa khas yang dapat menutupi aroma dan citra rasa ubi kayu yang cenderung tidak menyenangkan konsumen. Selama proses fermentasi terjadi pula penghilangan komponen penimbul warna dan protein yang dapat menyebabkan warna coklat ketika pengeringan. Pengolahan tepung mocaf sangat berguna salah satunya sebagai bahan baku pembuatan produk olahan kue. Tepung mocaf memiliki kandungan kalsium, fosfor dan serat yang lebih tinggi dibandingkan dengan tepung terigu.

Jahe merupakan salah satu jenis tanaman rempah-rempah yang ada di Indonesia. Komoditas ini dikenal sejak jaman penjajahan Belanda. Jahe (Zingiber officinale rosc) merupakan tanaman rempah-rempah yang dimanfaatkan sebagai minuman atau campuran pada berbagai bahan pangan. Rimpang jahe banyak dicari karena memiliki kelebihan dalam hal kesehatan, kesegaran, dan campuran untuk membuat masakan. Rasa jahe yang pedas disebabkan oleh senyawa keton zingeron sehingga bila dibuat minuman memberikan sensasi sebagai pelega dan penyegar tenggorokan juga bisa memberikan rasa hangat pada tubuh. Seiring dengan perkembangan teknologi dan makin meningkatnya kesadaran masyarakat akan pentingnya hidup sehat, pemanfaatan tanaman obat pun semakin berkembang. Pemanfaatan tanaman obat dengan ramuan tradisional dianggap sebagai media pengobatan alternatif yang lebih mudah dan murah untuk diterapkan dalam kehidupan sehari-hari. Pengolahan bahan makanan berupa bubuk jahe bertujuan memperpanjang masa simpan dan mempertahankan atau meningkatkan mutu nilai gizi. Selain sebagai bumbu masakan, bubuk jahe juga memiliki berbagai fungsi baik di bidang kesehatan misalnya, dapat meredakan rasa mual, untuk meningkatkan nafsu makan, mengurangi gejala mabuk, sebagai penyegar nafas alami, untuk meringankan nyeri, untuk mengatasi flu dan pilek, dan di bidang kecantikan untuk merampingkan tubuh.

Masyarakat mengolah tempe dengan cara sederhana, yaitu dengan cara digoreng biasa atau digoreng dengan tepung (masyarakat menyebutnya sebagainya "mendoan") atau ditumis $\underline{\text { saja. Tempe adalah makanan yang dibuat dari fermentasi terhadap biji kedelai atau beberapa }}$ 
bahan lain yang menggunajan jenis kapang Rhizopus, seperti Rhizopus oligosporus, Rhizopus oryzae, Rhizopus stolonifer (kapang roti), atau Rhizopus arrizus. Sediaan fermentasi tersebut dikenal sebagai "ragi tempe". Secara umum, tempe merupakan makanan yang tidak asing bagi masyarakat Indonesia, bahkan dunia. Kaum vegetarian di dunia biasanya menggunakan tempe sebagai bahan pengganti daging. Berdasarkan hasil penelitian, tempe mengandung beberapa kandungan gizi yang baik seperti protein, lemak, dan karbohidrat. Ketiga zat tersebut dapat dengan mudah dicerna oleh tubuh, sehingga tempe baik untuk dikonsumsi segala kelompok umur. Tempe juga memiliki khasiat untuk melawan radikal bebas, sehingga dapat menghambat proses penuaan dan mencegah terjadinya penyakit degenerative (seperti aterosklerosis, jantung coroner, diabetes mellitus, kanker, dan sebagainya). Selain itu, tempe juga mengandung zat antibakteri penyebab diare, penurun kolestrol darah, pencegah penyakit jantung, hipertensi, dan lain-lain.

Melihat fakta yang ada, mahasiswa KKN UAD tergerak untuk melakukan pengolahan singkong menjadi kue, jahe sebagai tanaman obat dan inovasi terhadap tempe. Mahasiswa berusaha untuk mengajak warga masyarakat mengolah singkong, jahe dan tempe menjadi olahan yang lebih variatif.

\section{METODE}

Untuk mencapi tujuan yang diharapkan, program pemberdayaan masyarakat di Desa Temuwuh ini dilakukan dengan cara memberikan pelatihan tentang cara pengolahan singkong, jahe dan tempe. Adapun ringkasan metode pelaksanaan pelatihan pengolahannya adalah sebagai berikut:

\section{a. Metode Mengolah Mocaf \\ 1. Alat dan Bahan :}

Alat dan bahan yang digunakan dalam proses pengolahan tepung mocaf untuk pembuatan produk olahan kue salah satunya chocolate melted brownies adalah : Pisau, loyang, Baskom, dan kompor. Sedangkan bahan yang digunakan adalah: tepung mocaf, mentega, dark cooking chocolate, gula pasir dan telur.

2. Prosedur Pembuatan

Proses pengolahan tepung mocaf untuk pembuatan kue brownies ini cukup mudah. Pembuatan brownies berbahan tepung mocaf ini diawali dengan mencairkan dark cooking chocolate kemudian ditambahkan mentega dan diaduk secara rata. Setelah itu telur dikocok bersama gula hingga mengembang serta pucat. Kemudian dimasukkan tepung mocaf dan cokelat bubuk yang sudah diayak, diaduk rata, disamping itu campuran dark cooking chocolate dan mentega dimasukkan kemudian diaduk rata. Adonan setengah dituang ke loyang kukus selama 10 menit, kemudian diberi meises dan 1 sachet susu kental manis cokelat, sisa adonan dituang. Setelah itu kukus kembali selama 25 menit, serta dihias brownies sesuai selera.

b. Metode Mengolah Jahe 
1. Alat dan Bahan :

Alat dan bahan yang digunakan dalam proses pengolahan jahe adalah : pisau, wajan, saringan, baskom, parutan, pengaduk, dan kompor. Bahan yang digunakan adalah: jahe emprit dan gula pasir.

2. Prosedur Pembuatan

Proses pengolahan jahe dilakukan dengan metode sangrai. Sangrai adalah proses menggoreng tanpa minyak. Pengolahan jahe diawali dengan mengupas jahe emprit dan dicuci hingga bersih. Jahe yang telah dicuci bersih kemudian diparut hingga halus. Hasil dari parutan jahe tersebut kemudian disaring ke dalam wajan tanpa perlu ditambah air lagi. kemudian dilakukan penambahan gula pasir dengan perbandingan 1:1. Kemudian dipanaskan hingga mendidih dengan api kecil hingga campuran sari jahe dan gula pasir menyerupai caramel. Dilakukan pengadukan secara cepat hingga terjadi kristal sampai akhirnya berubah menjadi bubuk jahe.

c. Metode Mengolah Tempe menjadi nugget

1. Alat dan bahan

Alat dan bahan yang digunakan dalam proses pengolahan tempe untuk pembuatan produk olahan nugget adalah: kompor gas, tabung gas, wajan, spatula, sendok, piring saji, baskom, pisau, telenan, cobek, serbet, nampan. Bahan yang digunakan adalah: tempe, air, minyak goreng, telur, tepung terigu, tepung roti, tepung panir, daun bawang, lada, garam, gula, bawang putih, penyedap rasa, saos.

2. Prosedur pembuatan

Menyiapkan seluruh alat dan bahan; kupas tempe dari bungkusnya, lalu potong kecilkecil; potongan tempe dikukus selama kurang lebih 20 menit; diangkat dan ditiriskan tempe hingga kering; tempe ditumbuk menggunakan cobek, hingga benar-benar halus (hal ini untuk mudahkan proses pencetakan dan penggorengan); tempe dilumatkan dalam baskom sambil ditambah bumbu-bumbu, yaitu garam, bawang putih, lada, gula pasir dalam takaran secukupnya; lalu, daun bawang diiris dalam ukuran kecil dan dicampurkan ke dalam adonan tempe; bentuk adonan tempe menjadi bentuk nugget yang diinginkan dengan menggunakan bantuan telapak tangan atau cetakan; nugget yang sudah dibentuk dimasukkan ke dalam putih telur, kemudian dicelupkan ke dalam tepung terigu; setelah itu nugget yang sudah dibalut tepung terigu, dicelupkan lagi ke dalam putih tepung kemudian dicelupkan ke dalam tepung panir, dipastikan proses pembaluran sempurna, sehingga seluruh bagian nugget dapat tertutup, goreng nugget dalam minyak yang tidak terlalu panas, digoreng hingga berwarna kuning emas.

\section{HASIL, PEMBAHASAN, DAN DAMPAK}

\section{a. Pengolahan Singkong menjadi Tepung Kue}

Proses pengolahan tepung mocaf untuk bahan pembuatan produk olahan kue merupakan salah satu cara pengolahan bahan makanan yang ekonomis, karena singkong adalah produk lokal Indonesia yang mudah tumbuh, mudah memeliharanya. Disamping itu mocaf dijadikan salah satu alternatif sumber karbohidrat yang relative lebih aman daripada terigu. 


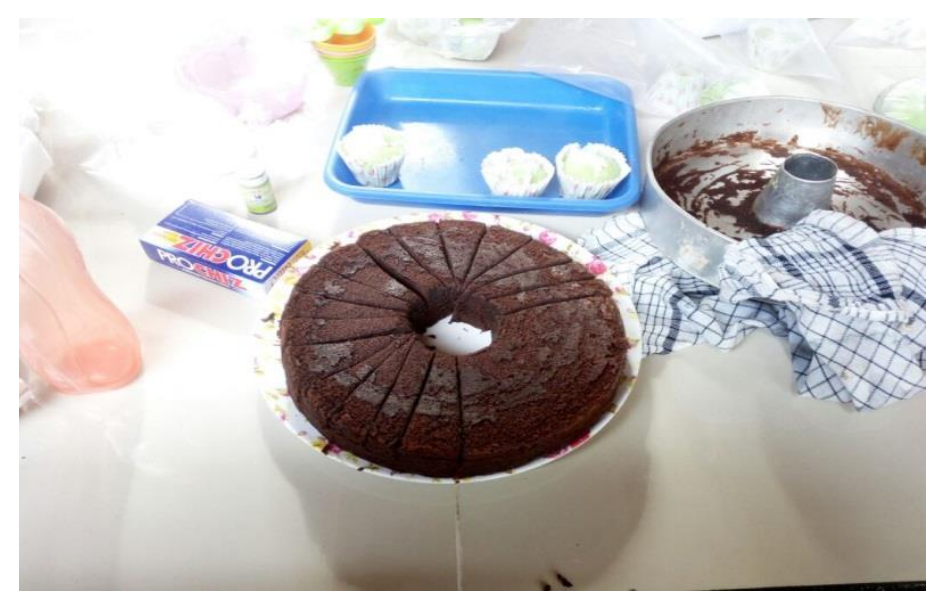

Gambar1. brownies coklat kukus

Program pelatihan pengolahan tepung mocaf untuk pembuatan makanan berupa kue brownies yang telah diadakan di dusun Kapingan, Temuwuh, Dlingo, Bantul ini mendapatkan respon positif dari masyarakat sekitar. Hal tersebut dapat dilihat dari banyaknya antusiasme masyarakat yang mengikuti kegiatan pelatihan tersebut. Meskipun tidak semua masyarakat Kapingan dapat mengikuti kegiatan pelatihan ini dikarenakan keterbatasan waktu pelaksanaan. Pada gambar 1, terlihat penampilan dari hasil pembuatan kue brownies coklat kukus yang dibuat oleh ibu-ibu dari dusun Kapingan.

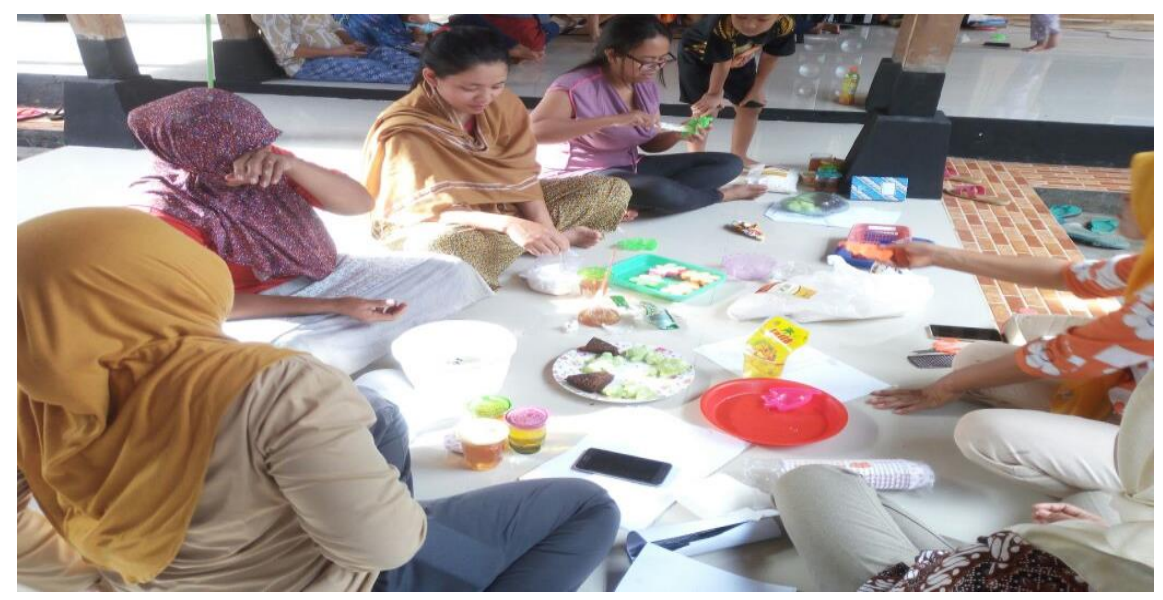

Gambar 2. antusias ibu-ibu saat pelatihan tepung mokaf

Dilihat dari gambar 2, masyarakat Kapingan memiliki antusias yang tinggi dalam pengolahan tepung mocaf untuk bahan pangan. Oleh karena itu dari KKN UAD memilih tepung mocaf sebagai salah satu bahan utama dalam pembuatan kue brownies. Dengan alasan karena tertarik dan lebih mudah serta ringan membuatnya. Warga sangat antusias dalam kegiatan pembuatan brownies, karena pada umumnya warga mempunyai alat-alat untuk membuat brownies. Dan setelah diadakannya kegiatan pembuatan brownies dengan tepung mocaf warga menjadi tahu tentang bagaimana cara membuat brownies dengan bahan yang lebih murah dan bisa mereka dapatkan dengan mudah di pasaran.

Tepung mocaf memiliki prospek pengembangan yang bagus. Karena belum adanya ketersediaan tepung mocaf yang dipasarkan didaerah Kapingan, desa Temuwuh untuk itu warga sangat senang dan memiliki rasa penasaran sehingga mau berpartisipasi dan mengikuti 
pelatihan pengolahan tepung mocaf. Disamping itu keunggulan lainnya yaitu harga lebih murah dibanding dengan harga tepung terigu maupun tepung beras serta dapat digunakan salah satunya dalam berbagai pembuatan kue. Hal ini tentu saja dapat menjadi faktor utama dari banyaknya antusiasme masyarakat yang mengikuti program pelatihan pengolahan tepung mocaf tersebut.

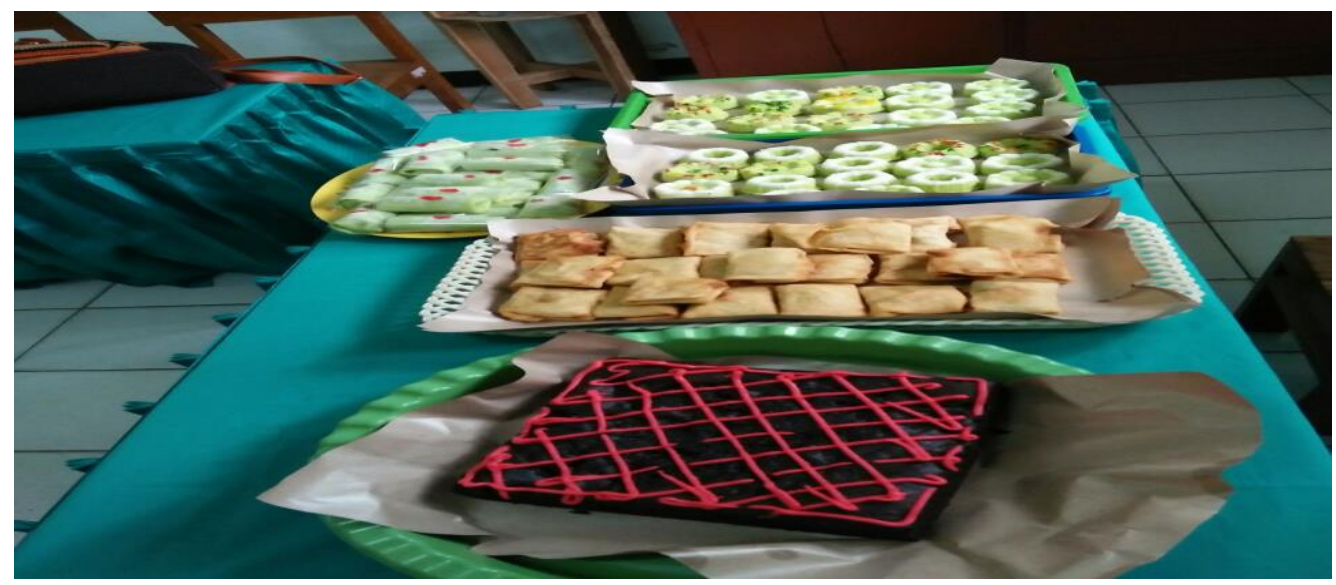

Gambar 3. Jajanan pasar dari tepung mocaf

Pada gambar 3, terlihat bahwa mokaf tidak hanya dapat diolah menjadi kue brownies saja, namun juga dapat diolah menjadi jajanan-jajanan pasar lainnya seperti : putu ayu, martabak, dan masih banyak lagi. Dengan diadakannya pelatihan tepung mokaf yang diolah menjadi kue dan jajanan pasar ini diharapkan dapat meningkatkan kreatifitas masyarakat Kapingan terutama ibu-ibu untuk mengembangkan kreasi dari tepung mocaf itu sendiri.

\section{b. Pengolahan Jahe menjadi Bubuk Jahe}

Proses pengolahan jahe dengan metode sangrai menghasilkan olahan berupa bubuk jahe. Pengolahan jahe dalam bentuk bubuk merupakan salah satu cara pegolahan bahan makanan yang paling sederhana sehingga dapat dilakukan oleh siapapun dan dimanapun.

Program pelatihan pengolahan bahan pangan jahe yang telah diadakan di dusun Jambewangi, Temuwuh, Dlingo, Bantul dengan mengundang 2 orang sebagai perwakilan dari tiap RT yang ada di dusun Jambewangi. Hal ini dilaksanakan dengan beberapa pertimbangan diantaranya yaitu keterbatasan tempat dan waktu pelaksanaan. Adapun sarana dan prasarana seperti alat dan bahan yang digunakan dalam program pelatihan ini murni diadakan oleh mahasiswa KKN UAD. Meskipun demikian, program pelatihan ini mendapatkan respon positif dari masyarakat sekitar. Hasilnya, sebanyak $80 \%$ masyarakat dusun Jambewangi yang mendapatkan undangan dapat hadir mengikuti kegiatan pelatihan tersebut.

Dilihat kembali dari keadaan geografis dusun Jambewangi yang terletak di dataran tinggi dengan suhu udara berkisar antara $23^{\circ} \mathrm{C}-32^{\circ} \mathrm{C}$ membuat minuman penghangat seperti jahe ini menjadi sangat dibutuhkan untuk menghangatkan tubuh atau hanya sekedar untuk menemani waktu senggang. Hal ini tentu saja dapat menjadi faktor utama dari antusiasme masyarakat yang mengikuti program pelatihan pengolahan jahe tersebut. Keuntungan lain 
dari pengolahan bubuk jahe sebagai bahan baku yang fleksibel untuk industri pegolahan makanan aman dalam distribusi serta menghemat ruang dalam penyimpanan.

Berikut ini dokumentasi kegiatan mahasiswa KKN UAD dan masyarakat dusun Jambewangi dalam program pelatihan pengolahan jahe tersaji pada gambar 1 .

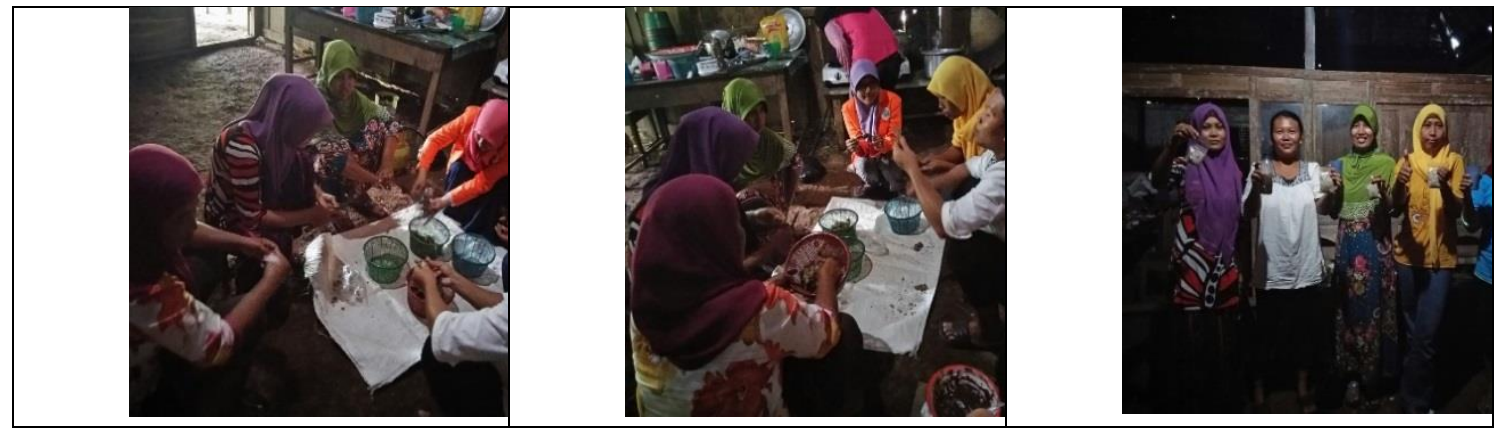

Gambar 4. Kegiatan pelatihan pengolahan bahan pangan jahe oleh mahasiswa KKN UAD dengan masyarakat Jambewangi

c. Pengolahan Tempe menjadi Nugget Tempe

Nugget tempe merupakan olahan tempe yang terbuat dari tempe halus yang dicetak dalam berbagai bentuk dan dilapisi dengan tepung berbumbu. Tempe halus yang dimaksud adalah tempe yang telah dipotong kecil-kecil, direbus kemudian dilumatkan hingga halus. Kelebihan dari nugget tempe ini adalah bahwa bahan baku utama yang digemari, mudah didapat, mudah diproduksi, dan terjangkai oleh warga masayarakat. Selain itu, proses pembuatannya juga lumayan praktis. Proses penggorengan tidak memakan waktu yang lama, lebih cepat dibandingkan dengan menggoreng nugget ayam.

Sebelumnya, perlu diketahui bahwa ada beberapa bahan yang harus disiapkan ketika hendak membuat nugget tempe. Bahan yang diperlukan antara lain adalah: tempe, air, minyak goreng, telur, tepung terigu, tepung roti, tepung panir, daun bawang, lada, garam, gula, bawang putih, penyedap rasa, saos, dan sebagainya. Peralatan yang dibutuhkan meliputi kompor gas, tabung gas, wajan, spatula, sendok, piring saji, baskom, pisau, telenan, cobek, serbet, nampan, dan sebagainya.
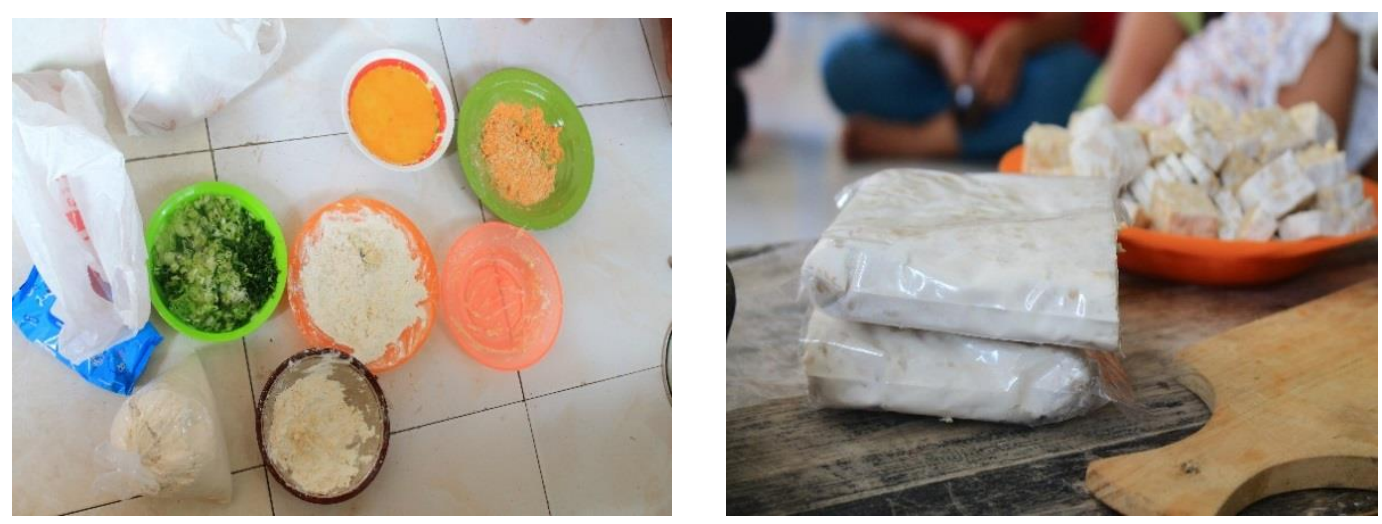

Gambar 5. Bahan baku pembuatan nugegt tempe 
Adapun untuk proses pembuatannya adalah sebagai berikut: (1) seluruh alat dan bahan disiapkan; (2) tempe dibuka dari bungkusnya, lalu dipotong kecil-kecil; (3) potongan tempe dikukus selama kurang lebih 20 menit; (4) tempe diangkat dan ditiriskan hingga kering; (5) tempe ditumbuk menggunakan cobek, hingga benar-benar halus (hal ini untuk mudahkan proses pencetakan dan penggorengan); (6) tempe dilumat dalam baskom sambil ditambah bumbu-bumbu, yaitu garam, bawang putih, lada, gula pasir dalam takaran secukupnya; (7) lalu, daun bawang diiris dalam ukuran kecil dan dicampurkan ke dalam adonan tempe; (8) adonan tempe dibentuk menjadi nugget yang diinginkan dengan menggunakan bantuan telapak tangan atau cetakan; (9) nugget yang sudah dibentuk dicepukan ke dalam putih telur, kemudian dicelupkan ke dalam tepung terigu; (10) setelah itu nugget yang sudah dibalut tepung terigu, dicelupkan lagi ke dalam putih tepur kemudian dicelupkan ke dalam tepung panir, dipastikan proses pembaluran sempurna, sehingga seluruh bagian nugget dapat tertutup, (11) goreng nugget dalam minyak yang tidak terlalu panas, digoreng hingga berwarna kuning emas.
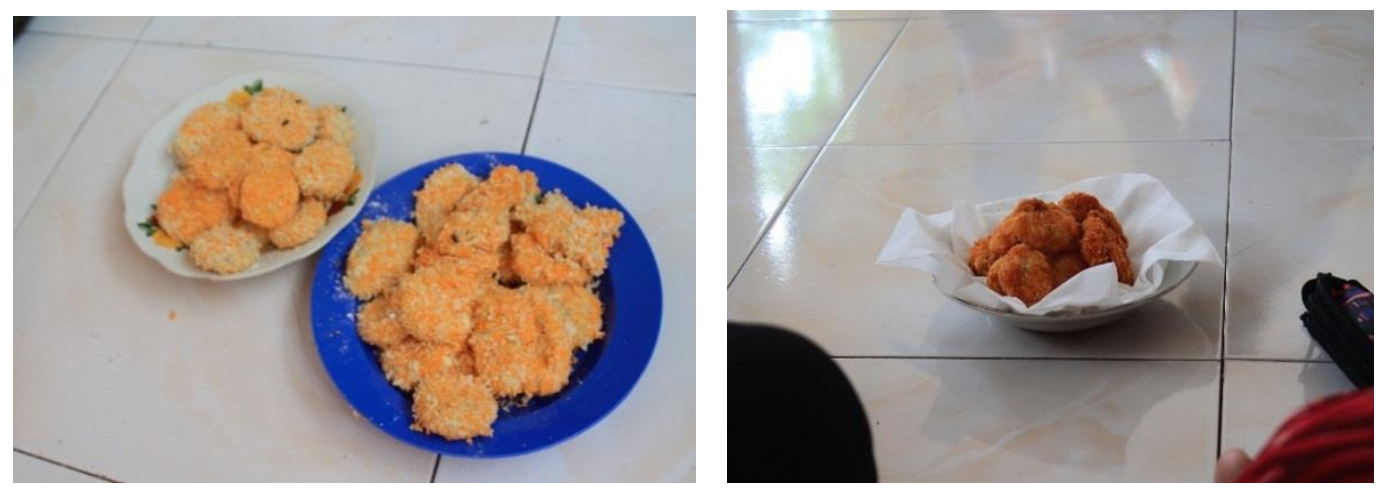

Gambar 6. Hasil pengolahan nugget tempe

Sebelumnya diberikan pelatihan para warga mengaku belum pernah membuat nugget. Mereka mengkonsumsi nugget yang sudah beredar di pasaran, dan belum tahu bagaimana cara membuatnya. Selama ini, mereka memahami bahwa nugget hanya bisa dibuat dari daging saja. Oleh karena itu, para warga sangat antusias terhadap pelatihan yang diberikan oleh mahasiswa. Dari hasil pelatihan ini, warga masyarakat mengaku bahwa mereka menjadi paham tentang khasiat dan kandungan yang ada di dalam tempe serta pentingnya bagi kesehatan. Dan yang paling penting, warga masyarakat mengaku mendapat tambahan pengetahuan tentang cara mengolah nugget tempe, karena masyarakat telah mempraktekkan (mengolah) secara langsung. Selain itu, warga masyarakat yang menjadi produsen tempe juga semakin semangat, karena peluang pasar tempe ternyata jauh lebih luas. Bahkan ada beberapa warga yang antusias bertanya tentang bahan lain apa yang bisa digunakan untuk membuat nugget, dan ingin melalukan percobaan sendiri di rumah. Hal ini mengindikasikan bahwa animo dan daya kreatif masyarakat semakin bertambah. 


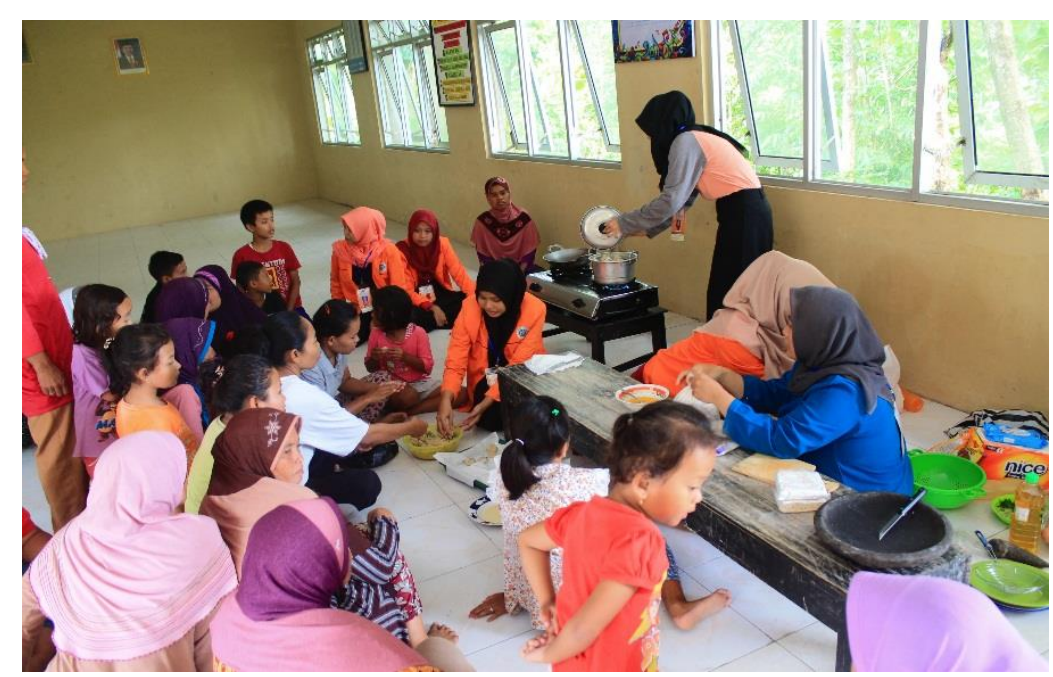

Gambar7. Praktek pembuatan nugget tempe

Pelatihan pengolahan nugget tempe itu sendiri dilakukan sebanyak 2 (dua) sesi, yaitu pada tanggal 30 Januari 2017 dan tanggal 09 Februari 2017. Tempat pelatihan berada di komplek Balai Pedukuhan Nglampengan. Pelatihan ini memakan waktu sekitar 2 (dua) jam untuk 1 (satu) sesi. Selama proses pelatihan berlangsung, warga masyarakat nampak antusias memperhatikan pemaparan tentang kandungan gizi tempe dan materi pengantar tentang nugget tempe. Warga masyarakat juga tidak sungkan untuk ikut praktek langsung, dari proses membuat adonan hingga proses penggorengan. Warga masyarakat juga tidak sungkan untuk bertanya dan berbagai pengalaman dengan mahasiswa KKN tentang berbagai bahan makanan yang bisa diolah menjadi nugget. Disamping itu, ketersediaan sarana dan prasarana cukup memadai, dimana tempat pelatihan yang luas dan dingin, bahan dan alat pembuatan nugget tersedia semua, kebutuhan akan listrik dan air juga telah terpenuhi. Adapun warga masyarakat menyampaikan kesan bahwa pelatihan nugget tempe ini sangat membantu warga masyarakat dalam membuat inovasi makanan dari tempe, dan dapat mempraktekkan dalam kehidupan sehari-hari. Warga masayarakat juga berpesan bahwa pelatihan semacam ini dapat lebih ditingkatkan dan dikembangkan di beberapa tempat maupun sasaran.

Adapun kendala yang dihadapi adalah jumlah sasaran yang tidak sesuai dengan target semula. Target yang ditetapkan semula adalah sebanyak 70 warga masyarakat Dusun Nglampengan, yaitu warga yang terdaftar dalam PKK Dusun Nglampengan. Akan tetapi, peserta yang hadir pada saat pelatihan hanya 43 orang. Hal ini dikarenakan beberapa warga (ibu-ibu) ada yang bekerja pada saat kegiatan pelatihan berlangsung, ada yang bekerja sebagai guru dan bekerja di pabrik. Para warga yang bekerja tersebut pulang ke rumah pada pukul 15.00 WIB, sedangkan pelatihan diadakan pada jam 10.00 WIB, sehingga tidak semua warga bisa mengikuti. Meskipun demikian, proses pelatihan pembuatan nugget tempe dapat berjalan dengan lancar, menghasilkan olahan nugget tempe dengan cita rasa yang enak serta berkesan bagi warga masyarakat Dusun Nglampengan.

\section{SIMPULAN}


Penyelenggaraan pelatihan pengolahan bahan pangan tradisonal menjadi lebih variatif dilakukan berdasarkan bahwa masyqrakat di Desa Temuwuh memiliki yang memiliki sumber pangan yang berlimpah, sehingga perlu adanya pengolahan yang inovatif agar masyarakat tidak bosan dan melupakan hasil pangan yang dimiliki, serta untuk memberdayakan warga masyarakat dalam membuat usaha berbasis makanan. Hasil signifikan dari adanya kegiatan ini adalah bertambahnya pengetahuan masyarakat tentang cara mengolah kue brownies mocaf, serbuk jahe dan nugget tempe dan berkembangnya suatu prospek usaha.

\section{DAFTAR PUSTAKA}

Afrianto, E.,2008, Pengawasan Mutu Bahan atau Produk Pangan. Bandung : Departemen Pendidikan Nasional.

Aliya., 2006. Aplikasi MOCAF (Modified Cassava Flour) pada produk Cake. Jember : Universitas Jember.

Badan Pusat Statistik (BPS).,2011., Konsumsi Tepung Terigu.Jakarta: Biro Pusat Statistik.

Basrah, A., et al. , 2005, Agroindustri Tanaman Obat, Status Perkembangan Produksi dan Pengolahan. Prosiding Forum Konsolidasi Strategi dan Koordinasi Pengembangan Agroindustri Tanaman Obat. Badan Penelitian dan Pengembangan Industri, Jakarta : PT. Gramedia.

Buku Data Arsip Kependudukan Desa Temuwuh, 2016, http://id.wikipedia.org, diakses pada tanggal 27 Februari 2017, pukul 14.05 WIB

Maghfiroh, I., 2000, Pengaruh Penambahan Bahan Pengikat Terhadap Karaktristik Nugget dari Ikan Patin (Pangasius hypothalamus). Skripsi. IPB.

Marsana. 2011. Optimasi Substitusi Tepung Terigu dengan Modified Cassava Flour pada Sistem Produksi Bahan Makanan Bolu Oven. Yogyakarta : UGM

Sunarsih, S., 2012. Memanfaatkan Singkong Menjadi MOCAF untuk Pemberdayaan Masyarakat Sumberejo. Sukoharjo: LPPM Universitas Bantara Sukoharjo.

Rohaya, Syarifah, dkk., 2013, Penggunaan Bahan Pengisi Terhadap Mutu Nugget Vegetarian Berbahan Dasar Tahu dan Tempe. Jurnal Teknologi dan Industri Pertanian Indonesia, Vol. (5), No. 1, 2013.

Rukmana, R., 2000, Usaha Tani Jahe. Kanisius. Yogyakarta 